\title{
視運動性平衡反射に対する前庭迷路系の modulation
}

一 視運動眼振発現に対する回転性前庭刺激の影響 —

\author{
玉 田彰 \\ Modulation of the Optokinetic Equilibrium Reflex \\ by Vestibular Labyrinthine Reflex
}

\author{
Akira Tamada \\ (Kyoto University)
}

The mutual interrelationships between the visual-ocular reflex (ViOR) and the vestibulo-ocular reflex (VeOR) are not completely understood yet. Optokinetic nystagmus $(\mathrm{OKN})$ during ViOR was produced by rotating light stripes (Jung type). The whole visual field OKN, peripheral OKN, foveal OKN and hemianopsic OKN were produced with a Miyoshi-Shirato device.

Rotating nystagmus (RN) during VeOR was induced by a rotating chair.

OKN and RN were applied simultaneously to the same subject in the same direction and then in the opposite direction and vise versa.

1) The combined velocity of OKN and $\mathrm{RN}$ in the whole visual field was always constant, regardless of the phase of rotation.

2) When the peripheral OKN and $\mathrm{RN}$ were combined in the same direction, the velocity of the peripheral OKN was increased about $10-20 \%$, compared to that in peripheral OKN only.

In contrast, when the peripheral $\mathrm{OKN}$ and $\mathrm{RN}$ were combined in the opposite direction, the velocity of the peripheral OKN was decreased about 10-20\%.

3) In most of the subjects it was difficult to produce foveal OKN, and when RN was added to this OKN, the foveal OKN was not changed at all or suppressed in all four phases of rotation.

4) When the hemianopsic OKN and RN were combined in the same direction, the velocity of the former was increased and when they were in the opposite direction, the velocity of the former was decreased, regardless of whether hemianopsic OKN was temporal or nasal, foveopetal or foveofugal.

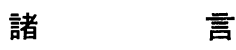

人や動物の平衡機能の維持に, 視器, 迷路, 深部並びに表在受容器の密接な相互の協力が必要で あることについては多くの支持がある。とくに視器, 迷路の平衡機能上の関連に関して, 福田, 桧, 時田 ${ }^{1)}$ らはウサギの眼振を観察して次の成績を得ている。すなわち域値下回転刺激とよばれる 
微弱な角加速度刺激 $\left(1.0 / \mathrm{sec}^{2}\right)$ でも, 視運動眼振の発現を促進し, 視器の外界の変化に対する適 応能力を著しく向上することを明らかにした。この成績は, 視器と迷路の平衡機能の関連を眼振を

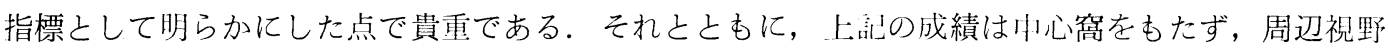
視のみで外界の運動に対応するウサギの場合には, 視器, 迷路の平衡機能上の関連は, 迷路（三半 規管）と網膜（周辺視野）の組合わせで成立するととを意味し，系統発生的にみて，乙の組合わせ が視器一迷路協応の原型となるととが示唆され，注目される。

さて人の場合はウサギの場合と異なり，小心窩が発育し，中心窩視が人の平衡維持で重要な意味 をもつとととなる. 従って, 視器一迷路の平衡機能上の関連を眼振を指標として採る場合にもウサ ギの場合とは異なった成績が得られる可能性がある。北原，佐藤 ${ }^{2}$ によると，正常成人では，微弱 な角加速度 $\left(1.0^{\circ} / \mathrm{sec}^{2}\right)$ を視運動刺激と組合わせる条件で実験を行うと, 次の成績が得られるとい う.すなわち右又は左へのスクリーン上に投影された綐の光の線条の右又は左への移動の速度が遅 い場合 $(12 \% / \mathrm{sec})$ には，上汇の角加速度刺激を加えて屯既存の視運動眼振には有為の変化はおてら ない．またての際，乙の視運動刺激に対して回転刺激が加わらなくても，被検者は一本，一本の線 条を明視しうると述べている。乙れに対し，120\%/secの様な高速の線条刺激が加わる祭には，被検 者はこの線条の動きを明視し得ず，視運動眼振の出現も活発ではない．この際 $1.0 \% / \mathrm{sec}^{2} の$ 角加速 度刺激が適時に加えられると, 主観的に線条の移動の朋視化がおこり, 客観的には視運動哏振の促 進化が现われる。乙のことより視器のみでは邈忍が困難な条件下では, 迷路は視器の平衡機能を促 進, 援助して, 視器の外界への適応能力を增大する役割を果たすと考えてよい.

以上 $2 つ の$ 実験より, 中心窩の発達により視器, 迷路の平衡機能上の関連にはある一定度の改変 を胃るが, 視器のみでは楜忍困難な外界の変化に対して, 前庭迷路は視器の平衡機能を促進するよ う作用するという点では共通している，但し，人の場合もウサギの場合と同じく，両者の機能上の 関速が，半規管一周辺祝野の組令わせで起こるのか，それとも半規管一川心简のそれで起こるの か，その点に関してなお検讨の余地が多い，乙の研究はその解明を目的の 1 つとている.

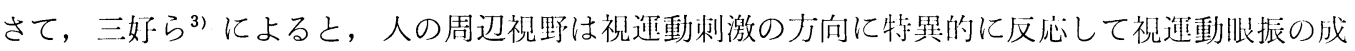
立に関与するという。すなわち彼等は彼等の考按した視野分離装置や鼻側, 耳側半盲フイルムを組 合わせて，中心窝を欠く人工的半吂を作製して実験し，次の結果を得ている，その成績を要約する と, foveopetal に祝運動刺激が加わる際には視運動哏振は朋膫に出现する, てれに比べ, foveofugal の視運動刺激に対しては眼振の発现は十分でない.

それでは人の埸合, 前庭迷路の視器への協応が起こる場合, foveopetal な祝運動刺激と迷路刺激 が組合わされる場合にそれが成立しやすいのか, それとも, foveofugal な视速動刺激に迷路刺激が 組合わされてもそれが成立しうるのか，乙の問題の解明はまだ十分になされていない.

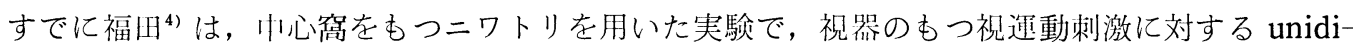
rectional は反応は，前庭迷路のもつ回転刺激に対する unidirectional な反応により相補され，動物 の外界への適応能力が向上する事実を見出している．但しウサギを対象とした同じ様な実験ではこ の様な相補は十分でない(小池, 1971 5) .

一般的に言って，人が自動的に，または他動的に運動する場合，自己の動的平衡を円洞に保つた めには，自己の連動とその運動によって生じた外界の假性運動との相対的位置のズレを的確に補正 する必要がある。そして，てのための有力な，最初の働き手は各種平衡器官の中でも視器であろ う。そして視器のみでは.上記のズレの補正を十分に行えない場合には，倜体は他の平衡器を動員し て視器を援助しその目的を達しようと努力するはずである。この際各平衡器の中で屯前庭迷路は動 
員されるにふさわしい平衡器と考えられる.

以上の様な事情をふまえて，私は以下述べる様な実験を試みた。すなわち与えられる右及び左へ の視運動刺激は一定速度とし, それを受ける視器（網膜）の側に人工的に種々の制約（周辺視野 視, 中心窩視, 鼻側並びに耳側半盲視野視など）を与えた。 そしてそれぞれの条件下での視器の外 界への変化への対応状態を視運動眼振で觀察し, それが同時に加えられる前庭迷路への回転刺激

（加速, 等速, 減速）でどのように変貌するかを究明した. 以下, それぞれの成績について申し述 べ, 人の回転運動中の視器と迷路の平衡機能上の関連についての私見を加えてみたい.

対

神経学的に異常所見を認めない正常成人 10 名

（男：女=9:1）を対象とした。年令の分布 は25才から34才までである。眼鏡をかけている

\section{象}

あのはそれを取りはずして裸眼で眼振記録が行 われている。

\section{実 験 方 法}

(1)刺激方法

Nagashima 製の総合眼球運動検査装置（N $\mathrm{K}$ 一 I ）を用いた。この装置には回転イス上に Jung 型の祝運動刺激装置を設置してある．従 って, 三半規管への刺激と視運動刺激をそれぞ れ単独に, 又は両者を組み合わせて刺激を加え るととが可能である。またとの視運動刺激装置 の投影器の下部には三好式祝野分離装置（図 1 ）を装着してある。乙の装置を用いて中心窩 $\mathrm{OKN}$ と周辺視野型 $\mathrm{OKN}$ を両眼誘渻した。 さらに片眼を遮蔽し, 開眼側の眼に耳側半盲 と鼻側半盲を人工的につくり，乙の条件下に foveopetal 及び foveofugal は視運動刺激を加 え, その際その眼から視運動眼振を誘導した。 なお记録はDC記録である。

三半規管への角加速度刺激は次のように行っ た.すなわち, 検者の頭部を前屈 $30^{\circ}$ の位置に おき， $0.5^{\circ} / \mathrm{sec}^{2}$ で 60 秒間持続して刺激を加え， 最高速度 $30^{\circ} / \mathrm{sec}$ に到らしめる. その後イスの 回転を 60 秒間 $30^{\circ} / \mathrm{sec}$ の一定速之する. 次いで $0.5^{\circ} / \mathrm{sec}^{2}$ の割合で減速を 60 秒間行い, イスを 停止する. 以下私達が行った実験条件をのべ る.

(2) a : 予備実験

実験 1 (回転眼振 Rotatory nystagmus-RN)
被検者を暗室で開眼の状態におき, 回転イス上 に $30^{\circ}$ 䫓位を前屈させて坐らせる。乙の条件下 に上述した角加速度刺激を加える。すなわち $0.5^{\circ} / \mathrm{sec}^{2}$ の加速, 減速刺激を各々 60 秒間行い, 両者の間に60秒間の $30^{\circ} / \mathrm{sec}$ の定速刺激を插入 する回転方法を行う。

実験 2（視運動性眼振 Optokinetic nystagmus-OKN）被検者の頭部をイス上に設けた䕱 台に圆定し， $60 \mathrm{~cm}$ 前方のスクリーン上を $30 \%$ $\sec$ の定速で回転する $30^{\circ}$ 間隔の線条を 60 秒間追 跡させる. 左及び右へ移動する線条刺激で誘発 される視運動性眼振をそれぞれ観察する.

b : 実験

央験 I ; 全視野視運動性刺激と回転イス刺激 を組み合わせる実験

30 \% sec の定速の線条をスクリーン上に投影 し，被検者にそれを60秒間追跡させる。

次いでこの視運動刺激を加えたままイスを $0.5^{\circ} / \mathrm{sec}^{2}$ の割合いで 60 秒間加速回転し, 迷路 刺激を加える. ひきつづいて $30^{\circ} / \mathrm{sec}$ の定速で 60 秒間回転イス刺激を加える。その後， $0.5 \%$ $\mathrm{sec}^{2}$ の割合でイスを減速回転（60秒間）する. イスの回転停止後さらに60秒間線条を追跡させ た。全検査時間は 5 分である。なおこの際視運 動刺激の方向と回転イスの回転方向は以下のべ 
る 4 種ある.なおこの実験での眼振の誘菜は両 眼誘導である。

実験 II 周辺視野視運動刺激と回転イス刺激 を組み合わせる実験

視野径 $20^{\circ}$ の中心暗点を前方のスクリーン上 に投影する。乙の条件下に視運動眼振を誘発 し，乙れに実験 I と同様の回転イス刺激を加え る.この実験でも，上述した 4 種の組み合わせで 眼振が観察されている。

実験 III ; 中心简視連動刺激と回転イス刺激を 組み合わせる実験

\begin{tabular}{c|c|c}
\hline 組み合わせ & 視運動刺激 & 回転刺激 \\
\hline 1 & 石 & 右 \\
2 & 右 & 左 \\
3 & 左 & 左 \\
4 & 左 & 右
\end{tabular}

視野径 $20^{\circ}$ の視野狭窄を前方のスクリーン上 に投影する。この条件下に視運動眼振を誘発 し，乙れに実験 I と同㥞の回転イス刺激を加え た。また視遇動刺激と回転イス刺激の組み合わ せは実験上でのべた組み合わせに準じた。

実験 $\mathrm{IV}$; 人工的半盲での視運動刺激と回転イ 又刺激を組み合わせる実験

白戸6) の方法に準拠して人工的半盲を作っ た。すなわち，中心窝を視野径 $20^{\circ}$ で遮蔽でき るように工夫された耳側半盲フイルムを用いて 人工的耳側半盲を作った。この条件下に視運動 刺激を加えた。なおこの実験では左腿は遮蔽 し，半盲を作製した右哏で眼振が记録されてい る。なおこの実験でも同栐の回転イス刺激を上 記の条件の視運動刺激と組み合わせている。

実験 $\mathrm{V}$; 鼻侧半妄用のフイルムを用いて鼻側 半盲を人工的に作製する。乙の条件下に視運動 性刺激を加えた。またこの実験では実験IVで述 べたと同じ回転イス刺激が加えられ，眼振は右 眼のみで記録されている。

\section{実 験 結 果}

\section{A : 予備実験の成績}

実験 I の成績; 回転眼振 : RN

$0.5^{\circ} / \mathrm{sec}^{2}$ の割合いで加速的にまた減速的に イスを用いて迷路刺激を加えると大多数の被検 者（10名中 7 名）では回転眼振は誘発されなか った。誘発されたものについて調査すると, 回 転イスの右回転では急速相が加速時右向きの, 減速時左向きの眼振が现われた。左回転では逆 の結果が得られた。しかしてれらの眼振はその 振幅が小で，打数も少なく，実験 I 及びП， III，IVの成績を決定的に左右するものではなか った.

実験 2 の成績; 視運動性眼振：OKN 大部分の被検者は右方向への視運動刺激では 左方向に急速相をむつ左 $\mathrm{OKN}$ ，左方向への それでは右方向に急速相をむつ右 $\mathrm{OKN}$ 艮好 に誘発した。

B : 実験成績
1 ）スクリーン上の線条の移動力向とイスの 回転方向が逆方向の場合

(i)回転イスが㺫速的に同転されている相での 成績

全視野に視運動刺激が加わっている条件下で は，イスが回され上氾の加速度刺激が加わって 屯既存の視運動性哏振の発现には有為の影響が あらわれ難い。例えば図 2 であげた代表例では 誘発される眼振の緩徐相速度は何れの条件下で も平均 $30^{\circ} / \mathrm{sec}$ で両者に有為の差をみない（図 2 - $\mathrm{a}$ 参照)。乙れに対し，周辺視野刺激で解発 される O K Nの緩徐相速度は約 $25^{\circ} / \mathrm{sec}$ であり, 全視野で誘発される OKNのそれより遅い。乙 の条件下で上記の $0.5^{\circ} / \mathrm{sec}^{2}$ の加速度刺激が加 わる場合は眼振の発現は促進的影響をうける。 すなわちその緩徐相速度は約 $28^{\circ} / \mathrm{sec}$ となる

（図 4 ）。乙の例の中心窩OK Nを検すると， 眼振之みなされるものは明瞭でない。乙の例で 
上記の加速度刺激を加えても有為の影響は現わ れない（図 $5-\mathrm{a}$ )。人工的耳側半盲, 鼻側半 盲の条件下では，乙こにあげた代表例では祝運 動性眼振の緩徐相速度はそれぞれ平均 $20^{\circ} / \mathrm{sec}$, $20 \% / \mathrm{sec}$ である。乙の両者に上記の角加速度刺 激を加えると，眼振の発現は明らかに促進的影 響をうける。すなわちそれぞれその緩徐相速度 は増大し， $22-24^{\circ} / \mathrm{sec} ， 24-26^{\circ} / \mathrm{sec}$ となる (図6, 図 9 ).

(ii)回転イスが等速に回転されている相での成 績

全視野に視運動刺激が加わっている条件で は，上記のイス回転が新たに加わっても既存の 視運動性眼振の発現には有為の影響をうけな い.すなわち眼振の緩徐相速度はそれぞれ $30^{\circ} /$ secである（図 $2-\mathrm{a}$ ). 周辺視野刺激で誘発 されている視運動性眼振はイスが定速回転に移 行して一定の時間（10２0秒）たつと視運動刺 激のみで誘発されていた際の眼振の発現に相似 した眼振を示し，その緩徐相速度は約 $25^{\circ} / \mathrm{sec}$ である（図4）。中心简 OKNでは上述したよ うに発现が極めて悪い，等速回転イス刺激が加 えられる条件下にもこの事情は変化しない（図 5-a). 耳側半盲, 鼻側半盲の条件下に視運 動眼振が誘発されている場合, これにイスの等 速刺激が加えられると，ある一定時間（10２0 秒）は加速時の眼振発現状況が続くが，それ以 後は加速前の状態の OK N 亿復起する（図 6, 図 9 ).

(ii)回転イスが成速的に回転されている相での 成績

全視野に視運動刺激が加わっている条件下 で，イスが $0.5^{\circ} / \mathrm{sec}^{2}$ の割合で減速回転される 場合に既存の眼振には有為の影響が現われな い.すなわちその緩徐相速度は約 $30^{\circ} / \mathrm{sec}$ であ る (図 $2-\mathrm{a})$ ） 乙れに対し周辺視野 $\mathrm{OKN}$ Nが 誘発されている場合, 上記のイス回転刺激が加 えられると眼振は明らかに抑制される。すなわ ちその緩徐相速度は約 $10 \%$ 減少する（図 4 ）。 中心窩OKNの発現はこの例では極めて不活発
である．乙の条件下に回転イスで減速回転が加 えられても眼振発現に関して有為の変動はない (図 5-a)。耳側半盲, 鼻側半盲の条件下の 視運動眼振に上記のイスの減速回転が加えられ ると, 既存の眼振には有為の抑制が現われる. すなわち，その眼振緩徐相速度は $15-18^{\circ} / \mathrm{sec}$ となり，平均約10２0\%の減少を示す（図6, 図9).

2 ）スクリーン上の線条の移動方向とイスの 回転方向が同方向の場合

(i)回転イスが加速的に回転されている相での 成績

全視野に視運動刺激が加わっている条件下で はイスが回され，上記の角加速度刺激が加わっ ても既存の視運動眼振の発現には有為の影響が 現われない。すなわち，何れの条件であ眼振緩 徐相速度は $30^{\circ} / \mathrm{sec}$ であ (図 $2-\mathrm{b}$ )。乙れに 対し, 周辺視野 $\mathrm{OKN}$ が発現している場合, 上 嗼の回転イス刺激が加わると既存の眼振は抑制 をうける，すなわちその緩徐相速度は約 $10 \% の$ 減少をみる（図 3 ）。中心窩 $\mathrm{OKN}$ Nはこの被検 者ではほとんど出現していない。これに上記の 回転イス刺激をあたえても明瞭な変化はみられ ない（図 5-b). 耳側半盲，鼻側半盲の条件 下に出現している視運動眼振の場合でも, 上記 のイス回転刺激時, 共に強い抑制作用を示す. すなわち, 回転イス刺激が加わると眼振緩徐相 速度は約 $10 \%$ 速度減少がみられるようになる (図 7 , 図 8 ).

(ii)回転イスが等速に回転されている相での成 績

全視野で視運動刺激が加わっている条件下で は，上記のイス回転が新たに加わっても既存の 眼振に有為の影響が現われない。すなわち， その眼振緩徐相速度は $30^{\circ} / \mathrm{sec}$ である（図 2 b ). 周辺視野 $\mathrm{OKN}$ 落誘発されている場合に は，イス回転が等速に移行して一定時間（約 10 〜20秒）は眼振の抑制をみる。それをすぎると 波形は大きくなりイス回転負荷前の状態に回復 する（図 3 ). 中心窩 $\mathrm{OKN}$ ）この例ではほと 
んど発現をみていない，等速回転イス刺激が加 えられてもこの状況に有為の変化はみられない (図 5-b). 耳側半盲, 鼻側半盲の条件下の 視運動眼振に等速回転刺激が加わると，ある一 定時間後眼振の波形は大となり，眼振の出現状 況は回転イス刺激前の状態に復起する（図 7, 図 8 ).

(ii)回転イスが成速的に回転している相での成 績

全視野OKNが発玩している際に上就の回転 イス刺激が加えられても視連動眼振と比べて有 為の変化を示す眼振は出現しない，すなわち眼 振緩徐相速度は $30^{\circ} / \mathrm{sec}$ である（図 $2-\mathrm{b}$ )。乙 れに対し，周辺視野 OKNが発玩している条件 下に上䛉のイス回転刺激が㺫わると眼振の振幅 は增大し，汃規则的に発現するようになる。 その緩徐相速度は約 $10 〜 20 \%$ の増川がみられる

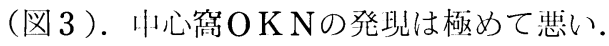
この条件下に上汒の回転イス刺激が打えられて も有為の変化はない（図 $5-b$ ). 耳側半盲,
鼻側半宣の条件下に出現している視運動眼振に 上汕の回転イス刺激が加わると，眼振の振幅は 大となり，その緩徐相速度は約 $10 \%$ の増加を示 している(図7, 図 8 ).

因みに，上記の周辺視野 $\mathrm{OKN}$ 之回転刺激の 結果は被検者 10 名中 7 名に見られた。残りの 3 名の成績は上訕の成績に必ずしも合致しなかっ た。例えばイスの回転が加速されても減速され ても其に眼振の発現が促進されたり，あるいは その逆に其に抑制をうけたり，上䛉とは全く反 対の結果を示した。またり心窩OKNに対する 角㞦速度刺激の影響について付言すると，上吔 の代表例ではこのOKNの出現が琹く，乙の条 件下に㺫速度刺激が㧈えられても有為の変化は なかった。

しかし川心窝OKNが出現していた埸合（10 例川 4 例）では回転イス刺激は加速, 等速, 減 速に関わらず既存の眼振を抑制する倾向を示し た。

\section{実験成績の総括}

1 ）全視野 OKNが発玩している場合は $0.5^{\circ}$ $/ \mathrm{sec}^{2}$ の加，減速刺激が加わっても前者の眼振 はほとんよ゙影響をうげない。

2 ) 周辺視野 $\mathrm{OKN}$ が発現している場合は, 回転刺激の方向により，また加速，減速の相の 違いにより対照する影響をうける。すなわち視 運動眼振と回転眼振が同力向に発現するような 組み合わせでは, 前者の眼振はイスの加速回転 では促進され，減速回転では抑制される，加速 回転より等速回転に移る場合ある一定時間は加 速回転の影響が残存する。

視運動眼振と回転眼振が逆力向に発現するよ うな組合わせでは，上䛉の組み合わせと刘照的 な成績が見られる。

3 ）一般的に中心窩 $\mathrm{OKN}$ Nをその発现が著し く悪い。乙れに上記の角加速度刺激が加わって あほとんどが有為の影響をうけないととが少な
くない。しかし回転イス刺激でこの眼振に影響 が現われるものもある。この際には加速，等 速，減速を問わず，抑制をうける倾向がみられ た.

4) 人工的に耳側及び鼻側半守を作製し，そ れぞれに foveopetal 及び foveofugal な視傕 動刺激を加えて眼振を誘発した。乙の眼振が $0.5^{\circ} / \mathrm{sec}^{2}$ の㑇加速度刺激でどの様な影響をう けるかを観察した。その結果, 視運動刺激の foveopetal 又は foveofugal の方向性之無関 係に2) で述べた傾向が見られた。なお人工的 半盲条件下では，あるJ向の刺激に視運動眼振 が誘発されない場合がある。乙の際に回転刺激 を加えても眼振の誘発をみないてとが多い。し かし中には回転刺激の負魚で眼振が誘発される あのがある．乙の時の誘発は上記の原則に従っ た. 
考

今回得られた成績を次の 2 点についてそれぞ れ考察を加えてみたい，第 1 は，視器と迷路の 協応を, 角加速度負荷時の全視野 $\mathrm{OKN}$, 周辺 視野 $\mathrm{OKN}$ 並びに中心窩 $\mathrm{OKN}$ の変動を指標と して得た成績について考察することである，第 2 は, 人工的半宣における視運動刺激の力向と 回転刺激の相関を眼振の変動を指標として得た 成績について考察することである。

さて上述したように，個体が自動的に又は他 動的に運動する場合，外界はその運動とは逆方 向に運動し，假性運動と呼ばれる現象が起こる ことがよく知られている。人や動物が円滑にそ の動的平衡機能を保つためには，個体の運動に 伴って起こる外界の変化と自己のそれの対応関 係が的確に実現され，網膜上の像のブレを来た さないように補正する機序が働く必要がある。 そのような観点から以上の 2 つ点について考 祭を加えてみたい.

まず第 1 の問題について考察したい.

(1)伤加速度刺激による全视野 $\mathrm{OKN}$, 周辺視 野 $\mathrm{OKN}$, 中心窩 $\mathrm{OKN}$ の変動

1) 全視野視運動刺激と回転イス刺激が組み 合わされる場合の成績：私達の正常成人を対象 とした成績では，回転イスが $0.5^{\circ} / \mathrm{sec}^{2}$ で加速 されても，減速されても，またての間に等速回 転運動が挿入されても，既存の視運動眼振（全 視野OKN）の発現は有為の影響を蒙らない. すなわち何れの回転刺激の相においてもその眼 振緩徐相速度は $30^{\circ} / \mathrm{sec}$ である。回転刺激（伤 加速度刺激）が加わっているのに，既存の視運 動眼振に有為の変化がみられないととについて の解釈は種々あらうが，次のように考えられて むよい，すなわち，乙の条件下には，視器系に foveo-retinal coordination が十分に成立し, 角加速度刺激が加わってもその状態が変化せ ず, 網膜上に像のブレが生じ難い故と考えられ る。乙の際，これまでの電気生理学的研究報告 を参照すると次のようにも理解される。すなわ ち, 視運動刺激と前庭迷路刺激による求心性イ
按

ンパルスが統合される有力な脳分野の 1 つは前 庭神経核であるとの報告 (Waespe et al.; 1977）を参照すると，前庭神経核の活動性は上 記の視運動刺激により十分に駆動され, 前庭迷 路上りの求心性刺激の流入が妨げられるか, あ るいは mask された状態にある。かくして既 存の視運動性眼振の発現には有為の変化が現わ れない。因みに，視運動眼振の発現に前庭神経 核が主要な神経要素になり得るか否かについて は，従来賛否両論があった。しかし最近の電気 生理学的研究報告をみる之, 迷路刺激（角加速 度刺激）は言うまでもなく, 視運動刺激によっ てもこの神経核の活動が変化することが明らか となっている (Waespe et al. ; 1977, 1979).

2 ) 周辺祝野視運動刺激と回転イス刺激が組 み合わされる場合の成績：従来の報告では人に おける optic-vestibular coordination の仕組 みは，全視野視運動刺激で誘発される視運動眼 振が角加速度刺激でどのように変化するかを観 察して検討されている。しかし人における視器 と迷路の平衡機能上の関連をさらに立入って考 察する場合には，周辺視野刺激で誘発される眼 振が迷路刺激（角加速度）でどのような変化を 遂げるのか，また中心窩視運動刺激で誘発され る眼振が迷路刺激でどのように変化するのか, それぞれを系統的に観察してみる必要がある. またてれまでの報告（例えば上記の北原らの報 告 ${ }^{2)}$ ) では, 回転イスが加速回転され，それが 既存の視運動眼振によ゙のような影響を持つかが 検討され，イスが娍速回転された場合の視運動 眼振の変化について問う処が少なかった。今回 私達の得た成績よりすると, (A)視運動眼振の出 現する方向と回転眼振（迷路眼振）が出現する 方向が一致するように組み合わされる場合，す なわち(イスクリーン上の縦の線条の移動する力 向（視運動刺激）と $0.5^{\circ} / \mathrm{sec}^{2}$ で加速回転され るイスの回転方向が逆方向の場合, (口スクリー ン上の線条の移動する才向と $0.5^{\circ} / \mathrm{sec}^{2}$ で減速 されるイスの回転方向が同方向の場合には既 
存の視運動眼拢の出現は促進される.例えば代 表例でのべたように，乙の条件下では周辺視野 $\mathrm{O}$ K Nの眼振綏徐相速度は $25^{\circ} / \mathrm{sec} よ り 28^{\circ} / \mathrm{sec}$ へと増強され，全視野 OKNのそれに近づく.

これに対し，(B)祝運動眼振の出現する才向と 回転眼振の出現する方向が互いに反対方向であ るように組み合わされる場合，すなわち，(1) ス クリーン上の線条の移動力向之 $0.5^{\circ} / \mathrm{sec}^{2}$ で減 速されるイス回転方向が反対方向の場合，(口) クリーン上の線条の移動方向と $0.5^{\circ} / \mathrm{sec}^{2}$ で加 速されるイスの回転方向が同方向の場合，には 既存の視運動眼振の発現は抑制される．上記の 代表例での成績では緩徐相速度に約10〜20\%の 減少を見ている。

従来の多くの報告では(A)一(1)の条件下に昌る 視器と迷路の協応の状態が観察の対伯とはなっ ている. 従って, 視器に対して前庭迷路は常に 促進的効果をもつ之理解されている.

さて，人の日常生活での連動で組み合わされ る視器と迷路の活動状況も多くの場合との条件 下である。しかし，人の回転連動は常に加速回 転ではなく，減速回転むある。従がって，その 際の視器に対して前庭迷路がどのような態度を 示すかを検討しておく必要がある。その意味で 今回, 回転運動中の視運動反射に対する迷路反 射の抑制相の存在するととを，人の視運動眼振 を指標として認め得た事は貴重と考える。

それでは中枢神経系においてはての際どのよ うな状況があたらされているのであろうか？ 人の成績ではないが赤毛ザルなどの高等哺乳動 物を用いて行った Waespe $\mathrm{e}^{7 / 8) 9(10) 11)}$ らの一連の 実験成績は示唆に富む. 彼らは視運動刺激が $60^{\circ} / \mathrm{sec}$ 以内の場合にはその刺激に対して前庭 神経核は応答し，それ以上の高度の視運動刺激 の場合には小脳片葉屯加わり，小脳片葉之前庭 神経核の相互交涉のもとに祝運動刺激に対する 态答が行なわれると言う。さらに，彼らは視運 動刺激と回転刺激の相互作用には方向特異性が あると述べている，すなわち両刺激が同方向に 作用する場合（上述の人の実験にあてはめる之
(A)の条件) には視運動刺激は迷路刺激で促進さ れる。乙れに対し，両刺激が互いに反対少向に 作用する場合（上述の人の実験では(B)の条件） には視運動眼振は迷路刺激の関与によりその発 現が抑制を受けるという。そして，ての両者の 刺激が統合される部位の 1 つに前庭神経核をあ げている，また，ての神経核では，眼振発現促 進時には神経細胞に活動性亢進の像（発火の增 大）が現われ，眼振抑制の相ではその神経細胞 に活動性抑制の像（発火の減少又は消失）が見 られるという。因みに，Waespe らは，眼振発 現促進時には純粋な視運動眼振又は回転眼振の 何れか優勢なすうに一致した発火が前庭神経核に 出现するという (Switch theory). これに対し $\tau$ Robinson $^{12)}$ は前庭神経核の視運動刺激と 回転刺激の統合は正確に加算的（Summation theory) であるという。何れにせよ, 両器官よ りの求心性インパルスが前庭神経核で統合され ることは人においてもあてはまるものであろ う。しかし，その統合が前庭神経核でのみ行な われるのか，それともそれと関連する他の脳分 野もそれに関与するかなどについては今後の検 討を要する．乙の問題については後の項でさら にとりあげてみたい.

さて，中心窩を欠くウサギの段階においても すでに optic-vestibular coordination が成立 することを眼振を指標として福田ら にしている。そして, 今回の実験で, 周辺視野 視で誘発される眼振が角加速度刺激で特徵的な 影響（促進又は抑制）をうける事実を知った。 このことは, 人においても回転運動中の視器と 前庭迷路の平衡機能上の関連の 1 つの形式は, 周辺視野一半規管の組み合わせであるととを示 し，貴重である.

3 ) 中心简視運動刺激と回転イス刺激が組み 合わされる場合の成績：中心窩の発達により， 視器系平衡機能が向上するととについては, 時

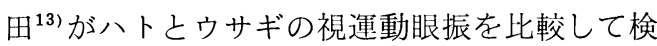
討している。言うまでもなく，前者は形態的に む明瞭な中心窩を有し，後者ではそれを欠いて 
いる．時田はハトで祝運動性平衡機能が発達し ている理由の 1 つにての点をあげている，従が って, 視器と迷路の平衡機能上の関連を人の眼 振を指標として論ずる場合にも，中心窩視運動 刺激で誘発される眼振に対する角加速度刺激の 影響を観察する必要がある. この際, 中心简 $\mathrm{O}$ KNの定義が問題となろう. 今回私達が行った 実験条件では視野径 $20^{\circ}$ の視野狭窄をスクリー ン上に投影している．従って文字通りの中心窩 視ではなく，周辺視野視を含んでいる．眼振が このような条件下で成立しているてとを前提と して上述の成績が論ぜられている.

今回私達が得た成績を再度要約すると次のよ うになる。

(1)一般的に言って中心䆚 $\mathrm{OKN}$ N楇辺視野 OKNのように明膫に発現するものは少なく, 眼振の出現が明膫でない場合には， $0.5^{\circ} / \mathrm{sec}^{2}$ の角加速度刺激でイスが加速的に又は減速的に 回されても, あるいは等速イス回転が行なわれ ても, 有為の変動はない.

(口) 角加速度刺激が与えられ, 中心窩 $\mathrm{OKN}$ に変化が見られた場合には，回転の何れの相 （加速，等速，減速）においても眼振はむしろ 抑制をうける傾向を示し, 周辺視野OKNでみ られる様な力向特異的な変化を示さなかった。

さて仲野 ${ }^{14)}$ によると, 外傷により中心暗点が 形成された患者の O K N 緩徐相速度は視運動刺 激として用いた線条の運動速度が低速の場合に はそれより速いこと（従って Hyper active optokinetic nystagmus の出現) を見出してい る. 彼はこの成績と類似する現像をイ又の網膜 中心領を損傷した場合にも一定期間（約 1 週 間）認めたという。乙れらの成績より, 視運動 眼振発現における人や動物の中心窩の周辺視野 への作用が, 対象物の運動が低速の場合は抑制 的であると結論している.もし仲野の考えが成 立するとすると, 中心窩視は角加速度刺激をう けて, 過剩に出現する周辺視野 $\mathrm{OKN}$ K抑制的 に作用することになる。ところで，上述した回 の項目で, 私達は角加速度刺激が加えられる場
合，中心窝 OKNには抑制傾向がみられること を述べた。乙の現象は仲野の考えと一定の関係 をもつのかも知れない。しかし，回転イスが加 速，等速，減速的に回転される場合，等しく眼 振に抑制傾向が見られるととや，イス回転が加 わっても中心窩 $\mathrm{OKN}$ 亿有為の変化を見ない場 合が少なくないととは，上記の仲野の考えを決 定的に支持し得ない，従って以上の成績を統合 すると次のようになる，すなわち，回転運動中 の人における中心窩之半規管の機能上の関連を 全面的に否定する資料を持合わせている訳では ないが，その関連の度は周辺視野と半規管のそ れに比べて小であると考えられる。それではこ の考えを支持するような報告がてれまでにもな されているであろうか. 以下紹介して見たい.

Buettner ${ }^{15)}$ らは，前庭神経核における visual suppression が暗室内で一点光を固視させ る場合と，明室で全視野視運動刺激が同方向に 与えられる場合とでは著しく異なり，後者にお いて有為にそれが起てることを述べている。 そ してての成績より中心窩よりも周辺視野への刺 激がより強力に前庭神経核への影響（この場 合は抑制）を与えるあのと考えている。また Waespe $ら^{8)}$ は視運動後眼振が一点光の注視と 全視野視運動刺激でごのような影響を受けるか を観察している.

その結果, 前者の場合は一時的に視運動後眼 振を抑制するが，後者の場合はそれを完全に抑 制するととをあげ，周辺視野と前庭神経核の より強力な結びつきを肯定している。てれらの 報告は, 只今私達が述べた考えと矛盾しない. 以上述べた成績を要約すると次のようになる. すなわち, 人の場合であ, 回転運動中の視器と 迷路の平衡機能上の関連は, 周辺視野一半規管 の組み合わせで起こることを本筋としている. この場合中枢神経系での前庭神経核（場合によ ってはこの神経核と小脸片葉) が重要な役割を 果し, また打そらく, 脳幹網様体むとれに関与 するあのと考えられる．乙こに脳幹網様体の関 与を考えるのは次の報告に依っている，すなわ 
ち, Moruzzi, Magoun ら ${ }^{17)}$ にると, すべて の somato-sensory な刺激は脳幹網様体七行 性賦活系に影響を与え, 乙の脳の活動のレベル を左右する．そして，その活動レベルにより人 や動物の意識のレベルや反射の度合が決定され る。また Teng ${ }^{18)}$ らにると脳幹網様体中 paramedian zone of the pontine reticular formation (PPRF) は視運動眼振速期の形成 に重要な関連をむつという。そして沢田 ${ }^{19)}$, 桧 $ら^{20)}$ によると, ウサギでの視運動眼振の発現が 活発である際には脳波に明暸な覚醒反応が出現 し, この眼振の出現が不活発の場合には覚醒反 応は明瞭でない。

以上の報告を参照すると, 祝器 (周辺視野) 之迷路（半規管）の活動性の相互交流の場を前 庭神経核と小脳片葉に限らず, 脳幹網㥞体をむ てれに加えて考察することは妥当と考える.

先に私達は実験成績を報告するにあたって， 回転刺激により凮辺視野 $\mathrm{OKN}$ Kが促進される場 合は線条の運動が明視しやすくなり，上記の眼 振が回転刺激で抑制される場合は線条の運動の 明視が困難になるとのべた。 この成績は眼振 （反射）の消長の背景に意識のレベルの変化が あることを肯定している。 そして，そのレベル の変化には上述したように脳幹網様体上行性賦 活系の関与は看過できない。また，乙の際脳幹 網様体の関与を考えることの妥当性は, 前庭神 経核と脳幹網様体の結びつきが脳神経系の線維 連絡の面からみても極めて密按であるという事 実よりも支持されよう。

(2)人工的半盲（中心简を欠く）に执ける視運 動刺激の方向之角加速度刺激の眼振発現におけ る関連

この問題を論ずる前に, 視運動刺激の才向と 眼振発現の相関についててれまでに報告された 論文の概略を紹介しておきたい。

福田, 時田 ${ }^{21)}$ はウサギ, モルモット，イヌ， ネコ, 人を対象とし, その片眼を遮蔽し, 視性 円筒 (Ohm 型) を回し，円周内面に付された 線条が開眼側より遮眼側に運動する場合と遮眼
側より開眼側にそれが運動する場合の視運動眼 振の発現状況を観察している。 その結果, 視神 経全交叉動物であるウサギ，モルモットでは後 者の視動物刺激に対して動物の反応は明瞭でな く，眼振も脊椎反射屯現われ難い。乙れに対 し，視神経不完全交叉のイヌやネコでは何れの 力向からの視運動刺激にも反応するが，その反 応の状況はやはり, 遮眼側より開眼側に向って 線条が移動する際には，その反対側に線条が移 動する場合に比べ眼振む脊椎反射もその発現の 度が低い，そして視神経半交叉の人においては 何れの力向からの視運動刺激に対しても良好に 反応し，眼振と脊椎反射を出現する。すなお ちウサギ，モルモットでは視運動刺激に対し， unidirectional response, があり,イヌ、ネコ では incomplete bidirectional response が出 現し，人に致ってはじめて complete bidirectional な反心が視運動性にもむたらされると 言ってよい. 人の半盲症例についてての種の報 告を述べると次の通りである，すなわち，三好 $ら^{3)}$ は半盲側より視界側への視運動刺激（foveofugal な刺激）では視運動眼振は成立し難 く，その逆に視界側より半盲側への視運動刺激 (foveopetal な刺激) に対しては十分に誘発 されると述べている。

さて今回の私達の成績では 10 例中 5 例が上述 の三好の成績と相似する成績を示した。

しかしのとりの 5 例ではその成績は必ずしむ 三好の述べた成績と一致しなかった。例えば 2 例では foveofugal な視運動刺激がより効果的 に祝運動眼振を出現するという成績をえてい る。また今回の実験では鼻側半盲の場合, 鼻側 より耳側に向う視運動刺激での眼振誘発の度合 は, 耳側半盲で耳側より鼻側に向う視運動刺激 で眼振が誘発される度合より高かった。この際 視運動刺激の方向之 fovea の関係からのみい えば，何れの場合も foveofugal な視運動刺激 となる，従って以上の様な善が生じたのは，鼻 側之耳側の網膜の視運動刺激受容性の差を示唆 するものであり，身体平衡機能の点から考えて 
も興味がある事例といえよう。

以上の様な報告を念頭におきながら，今回私 達が得た人工的半盲（中心窩を欠く）での視運 動眼振に対して回転刺激（加速，等速，減速） の影響がどのように現われるかを説明してみた い. その成績を要約すると次のようになる.

(イ）中心窩を欠く人工的半盲の場合でも, 眼 振が視運動刺激で誘発されている場合は, 中心 窩を欠く周辺視野 $\mathrm{OKN}$ の場合と同じく，回転 刺激の負荷により特徵的な影響をうける。すな わち視運動眼振の方向之回転眼振の方向が同方 向に組み合わされる場合（上述の実験(A)で述べ た条件と類似する条件）では眼振は促進され る. これに対し, 視運動眼振の方向と回転眼振 の方向が互いに反対方向に組み合わされる場合 （上述の実験(B)で述べた条件と相似する条件） では既存の視運動眼振は抑制される。従って中 心窩に対する視運動性刺激の力向 (foveopetal あるいは foveofugal）と回転刺激が直接的関 連をむって半盲時の視運動眼振の出現を支配す ることにはならない。

(口)上述の人工的半盲の場合, 視運動刺激を 加えても眼振が誘発されがたいむのがある（10 例中 3 例)。乙のような例で回転イス刺激が加 えられると，眼振を誘発するようになるものが ある ( 2 例)．乙のような例での眼振の消長は (1)で述べた原則が適用できる.

(メ)耳側半盲では foveopetal な視運動刺激 条件下では89\%に上記の原側に従った眼振の誘 発をみるが, 鼻側半盲のそれでは67～78\%にす ぎなかった。これに対して foveofugal な視運 動刺激条件下では耳側半盲が33\%の誘発しか示 さないのに, 鼻側半盲のそれは $55 \%$ の誘発を示 した（表1)。乙の結果は, 耳側網膜と鼻側網 膜に差があるためなのか. 視運動刺激が鼻側よ り耳側へ移動する方が, 耳側より鼻側へ移動す る場合に比べて, 網膜の感受性が高いためなの か今後の検討を要しよう（表 1 の対象数は 14 名 である).

さて，今回の実験に関連した論文を紹介する
と次のようなものがある。すすおち福田は視神 経全交叉動物であるニワトリを用いて，その片 眼を覆って，イスを加速的に回転 $\left(1.0^{\circ} / \mathrm{sec}^{2}\right)$ する際，視運動頭振がごのように変化を示すか を検討している。乙の際, $1.0^{\circ} / \mathrm{sec}^{2}$ の角加速度 刺激は回転中頭振を起こさない微弱な角加速度 刺激である，その結果次のととが判った。すな わちニワトリの場合は遮眼側より開眼側に視運 動刺激が加えられても視性頭振は起こり難い. しかしての条件の祝運動刺激（外界の假性運 動）が加わるように回転イスを遮眼側向きに回 した場合は，頭振が活発におこるととを見出し ている ${ }^{4)}$ ＼cjkstart福田はこの現象を全交叉動物のもつ 視運動刺激に対する unidirectional な反応が, 前庭迷路の屯つ角加速度刺激に対する unidirectional な反応に相補された結果と考え，新 しい角度加回転中の視器と迷路の平衡機能上 の関連を示した。しかし視神経半交叉動物を対 象として福田が述べたような成績が必ずしも得 られるものではない，例えば，小池地はウサギ を用いて同じような実験を行っているがニワト

表 | 半盲における $\mathrm{OKN}$ の方向特異性（右眼） Temporal hemianopsia

\begin{tabular}{c|c|c}
\hline $\begin{array}{c}\text { OKN } \\
\text { (刺激 }\end{array}$ & $\begin{array}{c}\mathrm{RN} \\
\text { 宫靣転 }\end{array}$ & $\%$ of induced nystagmus \\
\hline $\mathrm{R}$ & $\mathrm{R}$ & 89 \\
$\mathrm{R}$ & $\mathrm{L}$ & 89 \\
$\mathrm{~L}$ & $\mathrm{~L}$ & 33 \\
$\mathrm{~L}$ & $\mathrm{R}$ & 33
\end{tabular}

Nasal hemianopsia

\begin{tabular}{c|c|c}
\hline \hline OKN & RN & \% of induced nystagmus \\
\hline R & R & 55 \\
R & L & 55 \\
L & L & 67 \\
L & R & 78 \\
\multicolumn{2}{c}{ R=right } & L=left
\end{tabular}


リにみられるような十分な相補性を视器と迷路 の反射の間に認めていない，乙の差を山心窩の 存否に求めて良いか否かはなお不明であり，今 後の検討が必要であろう。

人の場合，䧓辺視野に半盲を人工的に作製し ても中心窩祝が妨げらていない場合は，foveopetal はむちろん foveofugal な視運動刺激 にも眼振が等しく良好に発現している ${ }^{3)}$. 従っ て，この条件下では人における視運動刺激の方 向之祝速動眼振の発現の相関を明らかにし得な い，それ故，人においてての問題を論ずるため には，中心简視を妨げた半盲を人工的に作製 し，視運動刺激を foveopetal 又は foveofugal に㞦えて出現する眼振を比較し観察する以外に なかった。また上記の視運動刺激の方向之回転 刺激が直峖的関連を有した眼振の発現に関係す るのか否かの検討も，中心窩を欠く半盲を人工 的に作製し，乙れに回転イス刺激を各種に変化 （加速，等速，娍速）させて加え，その際出現 する眼振の变動を僱察する力法を採らざるを得
なかった。そして，その実験結果は，上述した 通り, foveopetal, foveofugal な視運動刺激と 回転刺激が直接的に結びついて眼振の発現を左 右するものではなく，視運動眼振と回転眼振が 同方向に出現するように両刺激が組み合わされ ているのか，両刺激が互いに反対方向に向くよ うに刺激が組み合わされているのかが，眼振発 现を左右する重要な内子であることが判明し た.この成果は，上述したニワトリやウサギで 得た回転川の視器と迷路反射の相補性という条 件のみでは律しきれない問題を含んでいるよう に思う。

ヒトとニワトリ（视神経交叉の問題）， ニワ トリとウサギ（中心简視の問題）の成績の相違 を表出する因子は何であるか? それを䒚明する ような各種の条件を工夫して，乙の問題を今後 明らかにして行く必要がある。そして，そのよ うな過程を経て得た成績の蓄積により, 視器, 迷路の平衡機能上の関連の仕組みはより精緻な 解明を受けるものと考える。

\section{結}

語

人の回転りの視器之迷路の平衡機能上の関連の仕組みを明らかにするため, 次の実験を行った。 すなわち与えられる右及び左への祝運動刺激は一定速度とし，それをうける礼器（網膜）の側に人 工的に種々の条件（凮辺視野视，中心窩を欠く鼻側並びに耳側半盲祝）を作製した。そしてそれぞ れの条件下での視器の外界への適応状況を，その際出現する視運動眼振を観察して明らかにした。 ついで，それぞれの視運動眼振が同時に加えられる回転イス刺激（加速，等速，減速）でどのよう に変化を遂げるかを钼察し，人の回転運動中の祝器と迷路の平衡機能の関連を究明した。

得られた成績は以下の通りである。

(1) 全視野視運動刺激で誘発される視運動眼振は， $0.5^{\circ} / \mathrm{sec}^{2}$ の角加速度刺激で加速及び問速する 回転イス刺激を加えても有為の変化を認めなかった。

(2) 周辺視野視運動刺激で誘発される視運動眼振に上記の回転イス刺激が加えられると次の成績 が得られる。(1視運動眼振と回転眼振の力向が一致するよう両刺激が組み合わされる場合は，眼振 は促進される。吕両眼振の方向が互いに反対方向に出現するよう両刺激が組み合わされる場合は， 眼振は抑制される。

（3）中窩O K Nの場合は，(イとの眼振の発現が明膫でない場合は，回転イス刺激を（上述）を加 えても有意の変化はなかった。回ての眼振が出現している場合，回転イス刺激が加えられると，回 転の相（加速，等速，減速）の如何にかかわらず，眼振の抑制傾向が見られた.

（4）中心窩を火く人工的半盲で鼻側並びに耳側を作製し，その条件下に foveopetal, foveofugal の視運動刺激を加え，その際出現する眼振が上記の回転イス刺激でどのように変化するかを钼察し 
た．その結果，中心窩に対する視運動刺激の方向（foveopetal 又は foveofugal）と回転イス刺激 が直接関連して眼振の発現を左右するというより, 出現している視運動眼振の方向と回転眼振の方 向の組み合わせで眼振の発現が左右されることが判った。すなわちこの場合む(2)の原則が適用され るととを知った。

以上の成績より次の考えを述べた。

(1) 回転中の人の祝器と迷路の平衡機能上の関連は, 主として, 周辺視野と半規管の相互交涉に より実現される.

（2）中心䈑に対する視運動刺激の力向 (foveopetal, foveofugal) と角加速度刺激が直接関連し て, 眼振の発現を左右するものではなく, 祝運動眼振と回転眼振の方向の組み合わせで出現が左右 される.

実験に際して, 御指導頂いた桧学島根医大学長, 並びに三好豊二元京大助教授に深謝致します。

文

1) Fukuda, T., Hinoki, M., Tokita, T.: Provocation of labyrinthine reflex by visual stimuli. Acta Otolaryng $48: 425 \sim 432,1957$.

2 ) 北原正章, 佐藤利子：視運動刺激介在下における 人の迷路反射, 耳鼻臨床 $56: 574 \sim 578,1967$.

3 ) Miyoshi, T., Shirato, M., Hiwatashi, S. : Optokinetic nystagmus in artificial hemianopsy. Advance in O.R.L. 25:202 207, 1979.

4) Fukuda, T.: The unidirectionality of the labyrinthine reflex in relation to the unidirectionality of the optokinetic reflex. Acta Otolaryng $50: 507 \sim 516,1959$.

5 ) 小池 聰：回転刺激に対応する optic-vestibular coordination の発現と頸部深部受容器. 日 耳鼻 $74: 1363 \sim 1382,1971$.

6 ）白戸 勝：視運動眼振の発現機序. 耳鼻臨床 75 : 73 92, 1982.

7 ) Waespe, W., Henn, V. : Neuronal activity in the vestibular nuclei of the alert monkey during vestibular and optokinetic stimulation. Exp Brain Res 27:523 538, 1977.

8 ) Waespe, W., Henn, V.: The velocity response of vestibular nucleus neurons during vestibular, visual and combined angular acceleration. Exp Brain Res $37: 337 \sim 347$, 1979.

9) Waespe, W., Henn, V.: Conflicting visual

\section{献}

vestibular stimulation and vestibular nucleus activity in alert monkeys. Exp Brain Res $33: 203 \sim 211,1978$.

10) Waespe, W., Büttner, U., Henn, V. : Visualvestibular interaction in the flocculus of the alert monkey. I. Input activity. Exp Brain Res $43: 337 \sim 348,1981$.

11) Waespe, W., Henn, V.: Visual-vestibular interaction in the flocculus of the alert monkey. II. Purkinje cell activity. Exp Brain Res $43: 349 \sim 360,1981$.

12) Robinson, D.A. : Linear addition of optokinetic and vestibular signals in the vestibular nucleus. Exp Brain Res 30:447 450, 1977.

13）時田 喬：視機刺激の方向と眼筋骨格筋の反射形 式. 耳鼻臨床 $49: 752 \sim 774,1957$.

14）仲野紘介：固視パターンにより視運動眼振の研 究. 耳鼻臨床 $70: 147 \sim 176,1977$.

15) Buettner, U.W., Büttner, U.: Vestibular nuclei activity in the alert monkey during suppression of vestibular and optokinetic nystagmus. Exp Brain Res $37: 581 \sim 593$, 1979.

16) Lisberger, S.G., Miles, F. A., Optican, L. M., Eighmy, B.B. : Optokinetic response in monkey: underlying mechanism and their sensitivity to long-term adaptive changes in vestibloocular reflex. J. Neurophysiol 45 
: 869 890, 1981.

17) Moruzzi, G., Magoun, H.W. : Brain stem reticular formation and activation of the EEG. EEG Clin Neurophysiol I:455 473, 1949.

18) Teng, P., Schanzer, S., Bender, M. B. : Effects of brainstem lesions on optokinetic nystagmus in monkeys. Neurology (Minneap) $8: 22 \sim 26,1958$.

19）沢田克郎：神運動性刺激適応性獲得過程の脳波的 検討一家鬼の頭位上脳波と視性眼振を指標とする 観察一. 日耳鼻 $71 ： 1 \sim 19,1968$.
20）桧学, 沢田克郎, 近藤正彦：頸性「めまい」 発現に関する実験的研究一頸筋プロカイン注射の ウサギ大脳皮質脳波と視性眼振に及ぼす影響一耳 鼻臨床 $60: 27 \sim 37,1967$.

21) Fukuda, T., Tokita, T. : Über die Beziehung der Richtung der optishen Reize zu den Reflextypen der Augen und Skelettmuskeln. Acta Otolaryng 48:415 424, 1957.

原稿到着：昭和59年 1 月 7 日 別刷請求先：玉田 彰

T553 大阪市福島区福島 2 丁目 $1-7$ 関西電力病院耳鼻咽喉科 


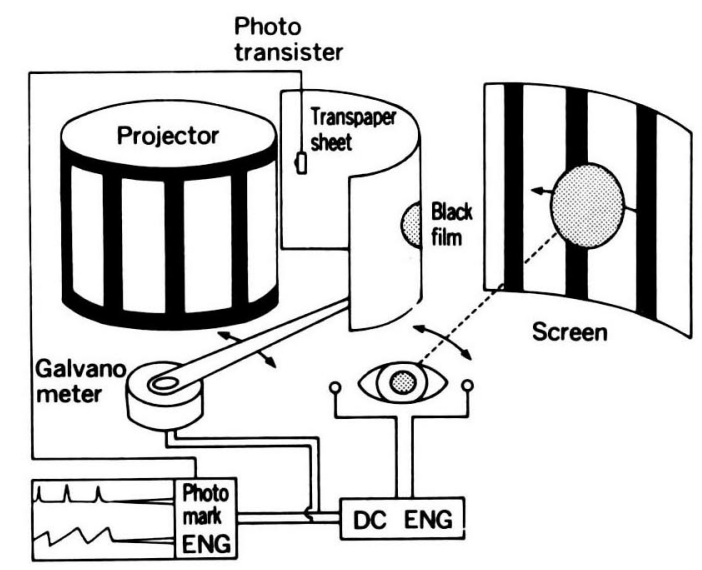

図 1 視野分離装置投影器の直下, 同軸上に置かれたガルバノメー夕改造の駆動装置の上に透明 円筒（図では内部が見えるようにその一部のみを描いてある）を，投影器の周りを包むように して置く. 透明円筒の正面中央に適当な形, 大きさの不透光黒色フィルムを貼付する. てのフ ィルムは図で見るように, スクリーン上に投影される光線条の一部を遮蔽して, 眼球に対する 同部からの刺激を消去する. 駆動装置は直流眼振計の出力で, 眼球と同じ方向, 同じ角度に動 かされる. このようにすると, 上記の刺激消去部分が, 視野の中でつねに一定の箇所となるの で, 恒常的な視野欠損を作り得る. 蔽光フィルムの形, 大きさを適当に選ぶと, 任意の形の視 野を作ることができる. 本図の場合は中心暗点となる. また, 投影器の前にフォトトランジス 夕を設置して光線条の通過した瞬間を眼振計上に記録し, 重ね合わせ法を行なえるようにした。

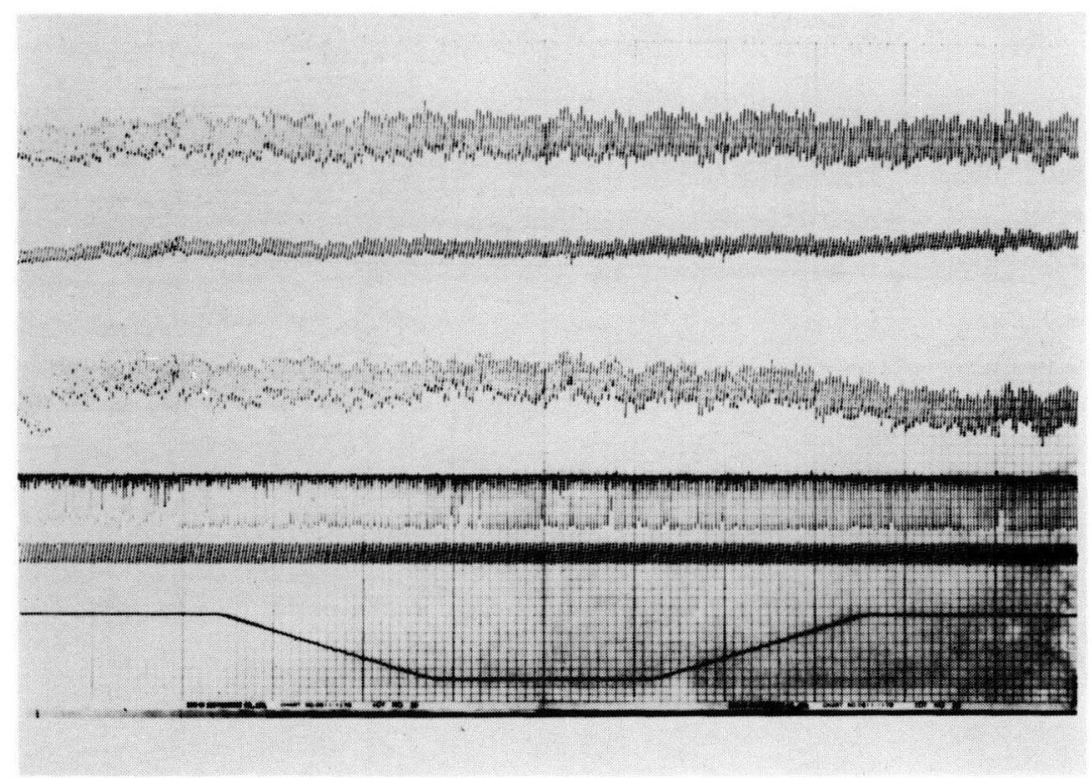

図 2 全視野OKNに対する回転眼振の影響

a) 左向き全視野O KN (上段) は左向き回転眼振 (下段) の加, 减速時にもほとんど変化を 示さず，きわめて規則的に正確に追跡がおてなわれている(緩徐相速度約 $30^{\circ} / \mathrm{sec}$ )

上より全視野 $\mathrm{K} \mathrm{N}$ N両眼, 右眼, 左眼, 両眼の速度波形視運動刺激, 回転イスの軌跡を示す. 上方が右向きで下方が左向きである. 二段目の右眼の gain は両眼, 左眼より小さくしてある. 


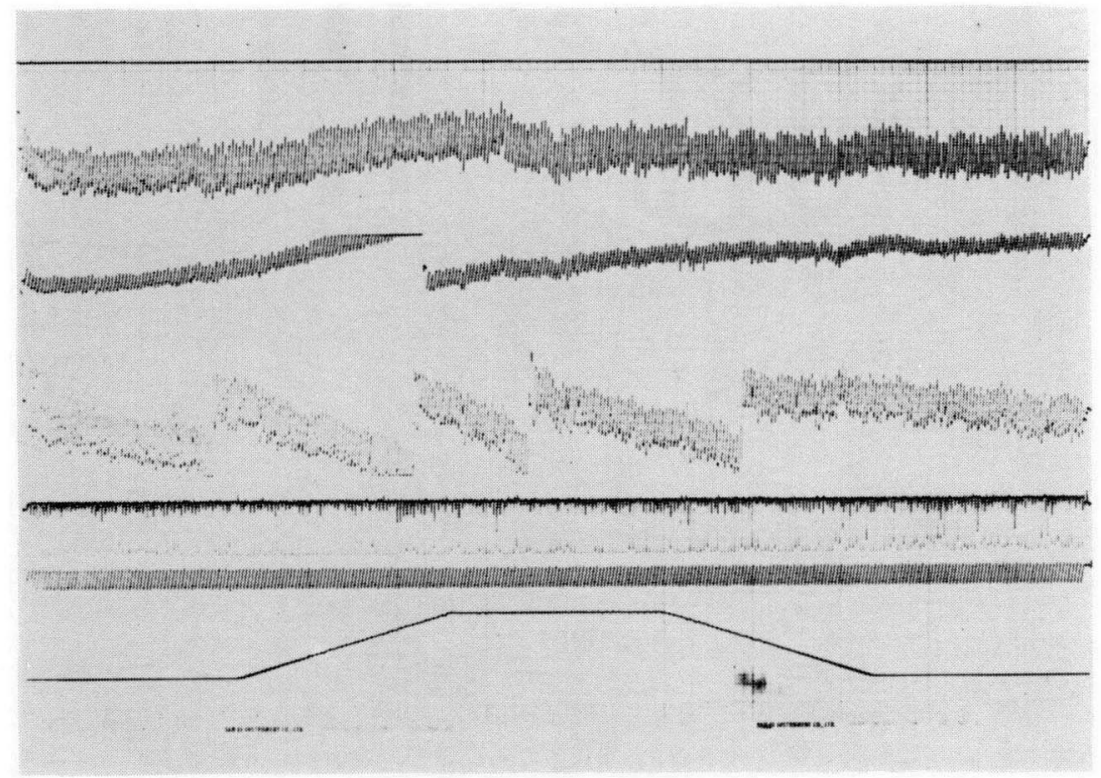

b ）左向き全視野O K Nは右向き回転眼振の影響を同様に全経過中ほとんどうけない.

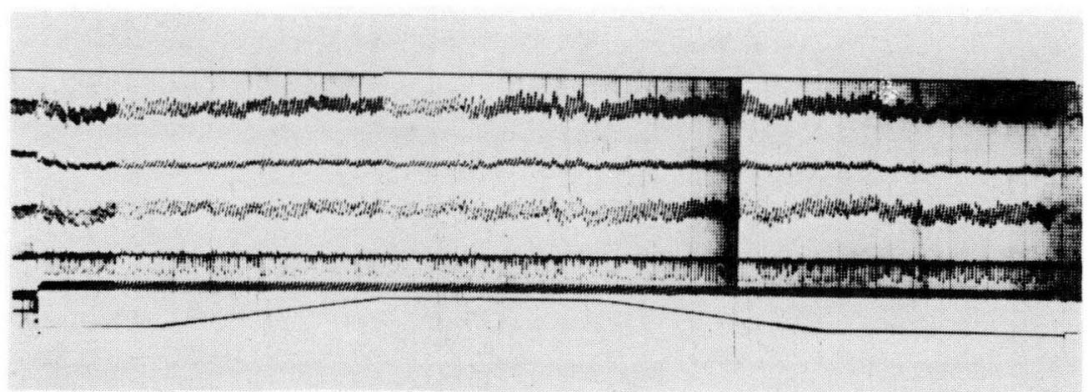

図 3 周辺視野性 $\mathrm{OK} \mathrm{N}$ K（緩徐相速度 $25^{\circ} / \mathrm{sec}$ ） に対する回転眼振の影響（急速相が逆方向の 時）左向きOKN（上段）に対して右向き回転眼振（下段）は加速時振幅の減少と，波形の乱 れを示すが, 减速時には振幅の増大と, 波形の整えを示す. 緩徐相速度では約 $10 \sim 20 \%$ 減少 及び増大として現われる.

上段より下段のグラフは図 2 に準ずる. 


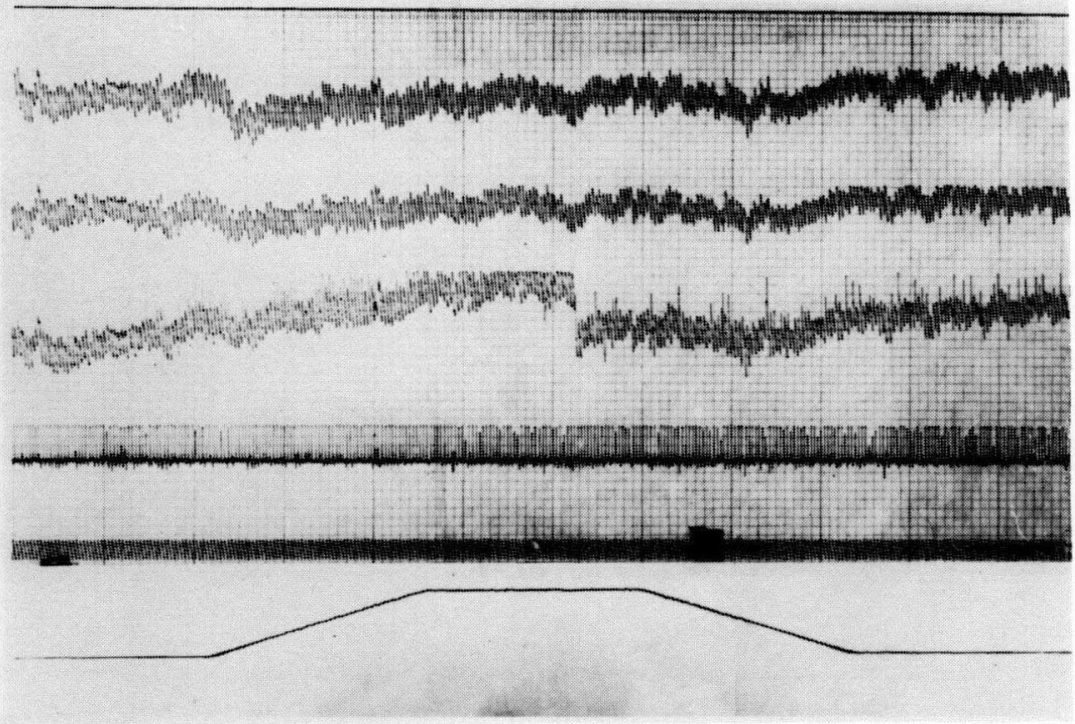

図 4 周辺視野性O K Nに（緩徐相度 $25 \%$ sec）に対する回転眼振の影響（急速相が同方向の時） 右向き $\mathrm{OKN}$ (上段) に対して右向き回転眼振（下段）は加速時, O K Nの振幅の增大と波形 の三角化を, 減速時には振幅の減少と波形の乱れを示す. 緩徐相速度では約10２0\%の增大又 は抑制として現われる．上段より下段へのグラフは図に準ずる。

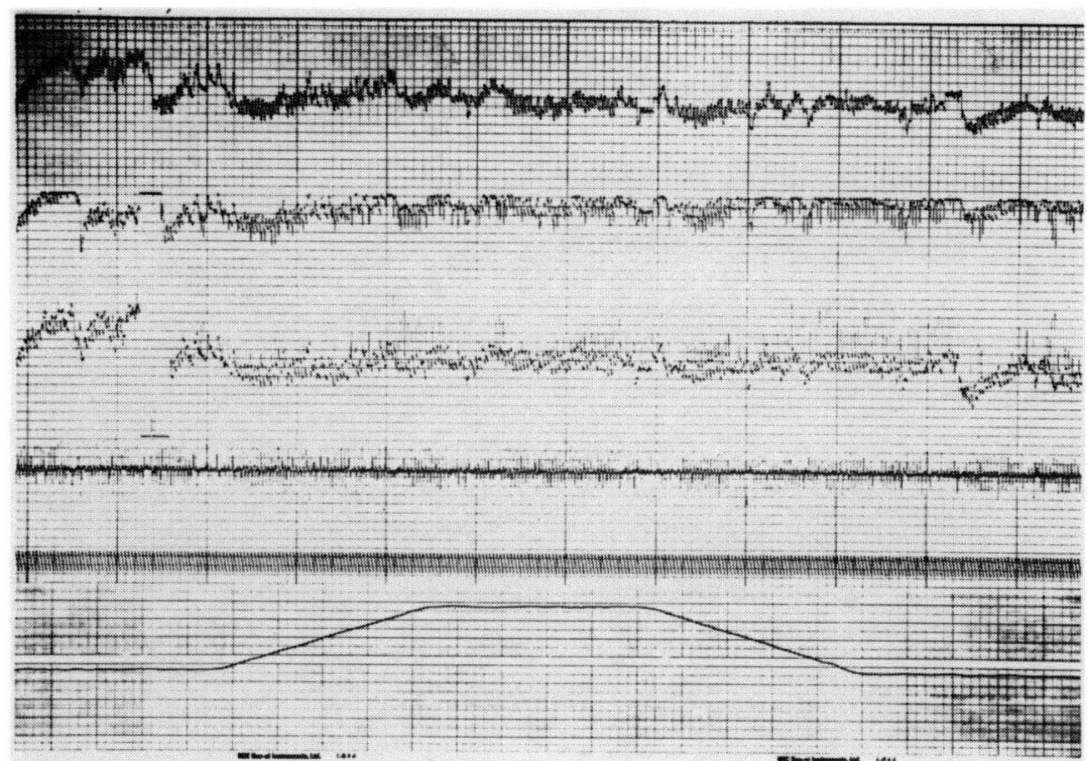

図 5 中心窩 $\mathrm{OKN}$ (緩徐相速度 $20^{\circ} / \mathrm{sec}$ ) 亿対する回転眼振の影響

a) 右向きOKNは上手に追えていないが右向きの加速の開始と共に一層抑制され，定速回転

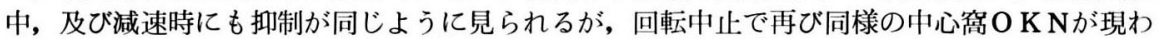
れる. 


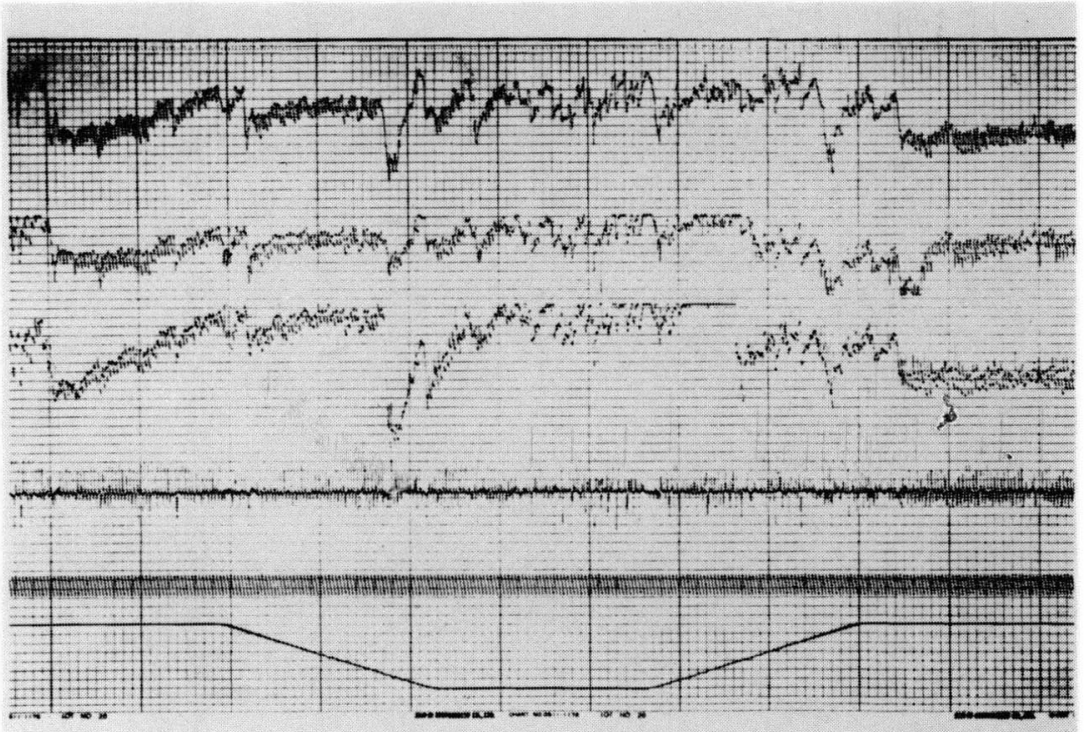

b ）右向きOKNの出現はかなり不良であるが，左向き回転の加速が加わるにつれてOKNは 強く抑制され，定速回転中 $\mathrm{K} \mathrm{K}$ Nはほとんど現われない，堿速時も強く抑制されたままで，減

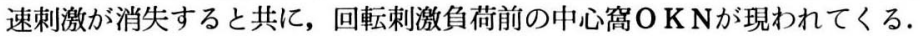

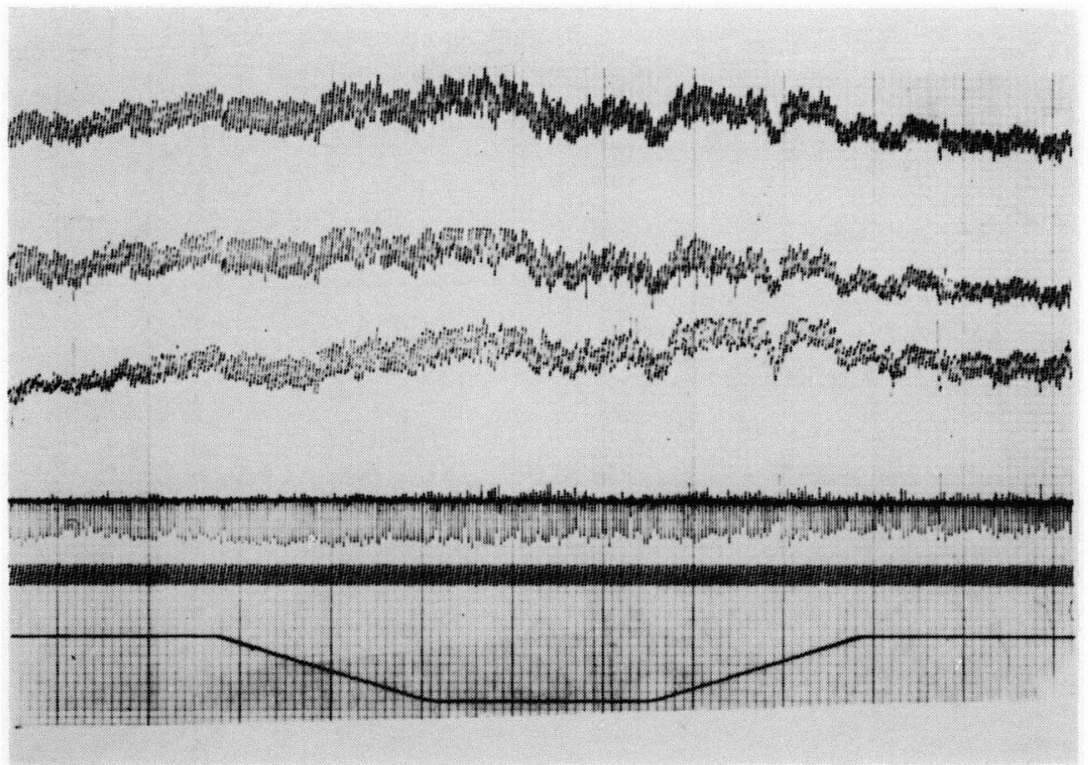

图 6 耳側半盲の左向き OKN (foveopetal) （緩徐相速度約 $20^{\circ} / \mathrm{sec}$ ) に対する左向き回転眼 振の影響

回転刺激の加速時にはO K Nの振幅は増大し，波形は整うが，減速時には $\mathrm{OKN}$ の振幅は減少 し，波形は乱れる．緩徐相速度では約10～20\%の増大又は減少を示す。 


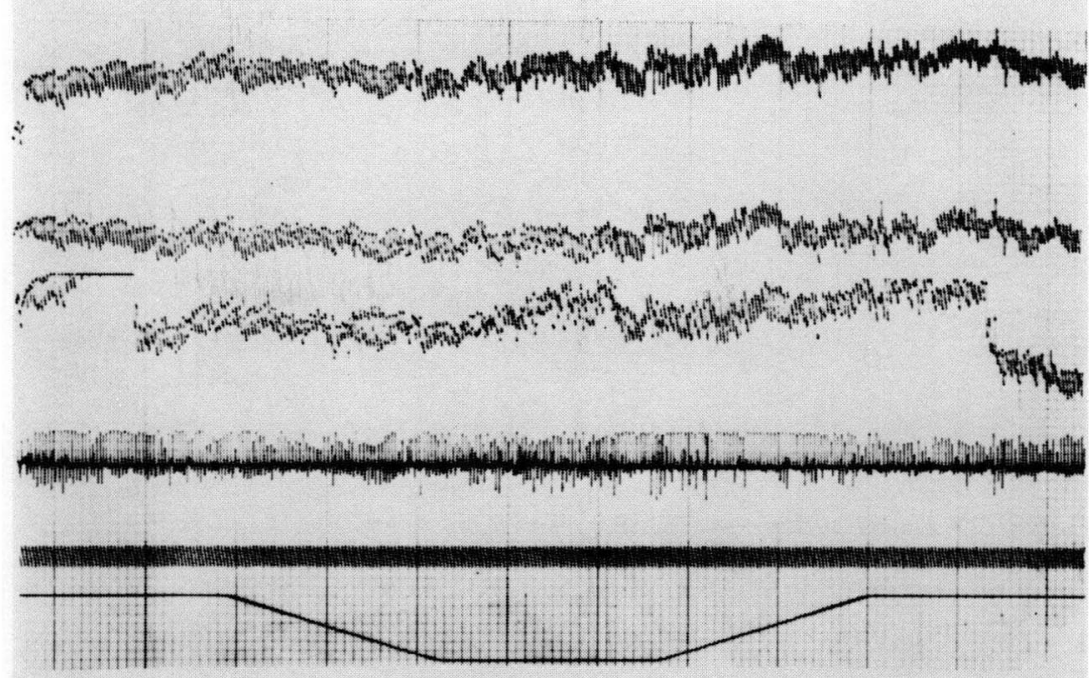

図 7 耳側半盲の右向き OKN (foveofugal) に対する左向き回転眼振の影響 foveofugal にもかかわらず $\mathrm{K} \mathrm{N}$ は良好に誘発されている．回転刺激の加速時にはO K Nの 振幅は减少し, 波形は乱れるが, 減速時には増大し, 波形は整う。

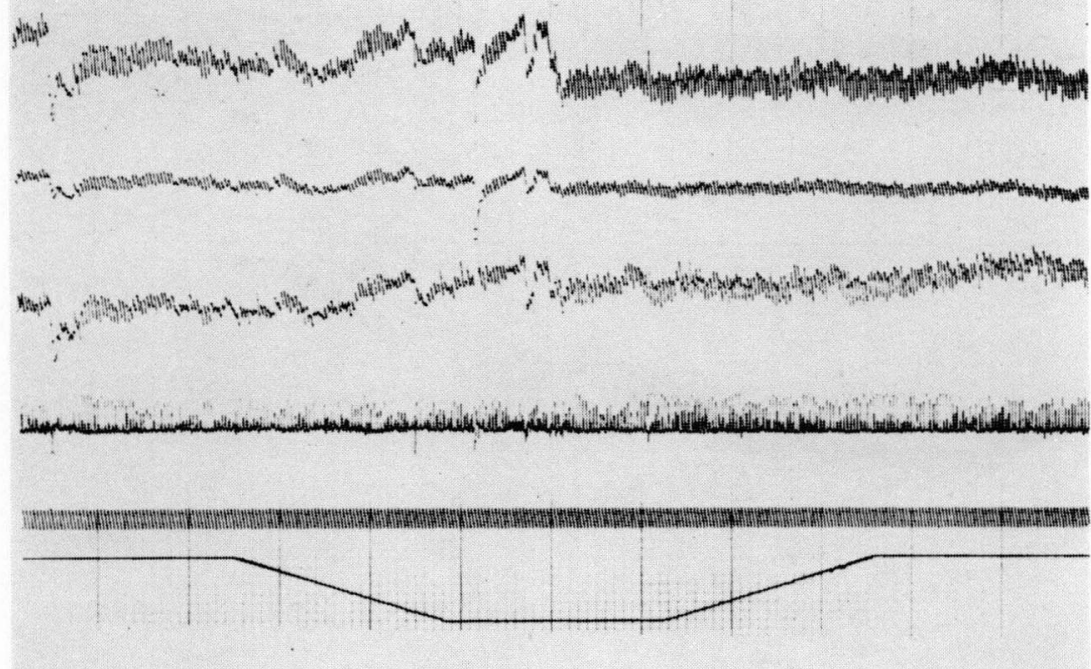

図 8 鼻側半盲の右向き $\mathrm{OKN}$ (foveopetal) (緩徐相速度 $20 \%$ sec) に対する左向き回転眼振の影響 回転刺激の加速時にはO K Nの振幅は诚少し, 波形は乱れるが, 減速時には增大し, 波形は整 う. 緩徐相速度では約10２0\%の減少又は増大を示す。 


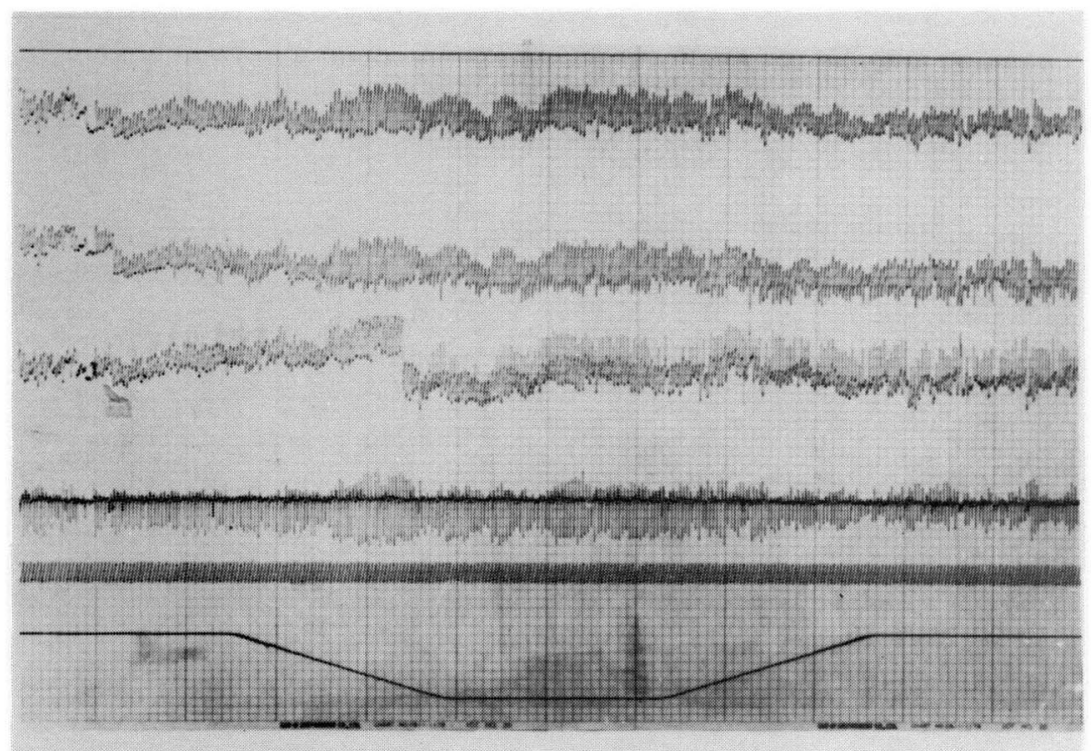

図 9 鼻側半目の左向き OKN (foveofugal) 亿対する左向き回転眼振の影響 foveofugal にもかかわらずO K Nは良好に誘発されている．回転刺激の加速時にはOKNの 増大が，減速時には堿少がみられる。 